\title{
Siła filozofii, filozofia siły
}

\author{
Janusz A. MAJCHEREK*
}

\begin{abstract}
The power of philosophy, philosophy of power: Selfless search for truth does not only make sense of philosophy and science, but also involves participating in a competition between rival theories and hypotheses. Truth is not an ultimate criterion in this process, especially after Michel Foucault revealed its inclinations towards violence. Questioning the position of truth opens the door to different criteria, among them - power. Using the argument of power in philosophical disputes and scientific controversies has a long tradition and nowadays with the unprecedented development of technology it has been offered new tools.
\end{abstract}

\section{KEYWORDS}

domination; violence; truth

* Prof. dr hab., Instytut Filozofii i Socjologii, Uniwersytet Pedagogiczny w Krakowie. Dyrektor IFiS UP. E-mail: janumaj@ists.pl. 


\section{PRAWDA I PRZEMOC}

Chociaż filozofowie chętnie powołują się na sentencję plus ratio quam vis, wielu z nich pielęgnuje niekoniecznie skrywane marzenie o dysponowaniu siłą, która pozwoliłaby narzucić lub przynajmniej utrwalić ich koncepcje nie tylko w intelektualnym obiegu, lecz także w społecznej praktyce. Patronuje temu marzeniu Platon, formułujący projekt państwa autorytarnego, zarządzanego przez filozofów kierujących się jego naukami, czyli przede wszystkim koncepcją trójdzielności duszy i paralelnej do niej struktury społecznej. Bodaj najdobitniej wyrazit to marzenie Karl Marx, deklarując, że filozofowie nie powinni poprzestawać na objaśnianiu świata, lecz śmiało go zmieniać. Znów, oczywiście, zgodnie z jego teorią, której wdrożenie wymagałoby zaprowadzenia dyktatury (proletariatu). „W jego przewidywaniu / życzeniu tkwiła odwieczna tęsknota za rządami królów filozofów" (Bartula, 2019: 120). Nieprzypadkowo i nie bez racji Karl Popper uznał Platona i Marxa za patronów totalitaryzmu. Marzenia greckiego filozofa pozostały niezrealizowane, bo próby ich urzeczywistnienia pod kuratelą i przy współudziale tyrana Syrakuz skończyły się fiaskiem. Projekty Marxa, niestety, zostały poddane bardziej zaawansowanym próbom wprowadzenia w życie, prowadząc do erupcji masowej przemocy i zbrodni. Siła sprawcza, mająca wcielać filozoficzne doktryny w życie społeczne, okazała się zinstytucjonalizowanym gwałtem.

Jednak Platońskie koncepcje też nie pozostały bez ponurych skutków praktycznych. Doktryna wrodzonej wiedzy, którą jedynie trzeba wydobyć z wnętrza duszy na jaw, legitymizowała inkwizycyjną praktykę tortur. Skoro w głębi duszy osadzona jest wymagająca ujawnienia wiedza, to usprawiedliwione są metody do niego prowadzace. W swobodnych, spontanicznych wypowiedziach każdy może mówić, co chce. Pod odpowiednio silnym przymusem wypowiada to, co głęboko ukryte w zakamarkach duszy. Prawdę trzeba wydusić. Jej wydobycie usprawiedliwia więc przemoc. Torturowani prawie zawsze ujawniają najgłębiej skrywane treści.

Platon tej praktyki nie wytworzył, on nadał jej filozoficzne uzasadnienie i dokonat rozszerzenia.

W greckim systemie prawnym torturowanie niewolników występowało jako gwarancja prawdy. Prawdę przekazują słowa torturowanego niewolnika, tortura musi wydobyć prawdę z ukrycia. [...] Wydobywane przez torturujących, dane te pochodzą z odrębnego typu ładu, nie są tym samym, co wypowiedzi świadków odpowiadających przed sądem z wolnej stopy (Zybertowicz, 1995: 240).

Tę metodę, zdaniem Page duBois - autorki rozprawy Torture and truth Platon rozciągnął na wszystkich ludzi i ufilozoficznił. „To znaczące przesunięcie; państwowa przemoc wobec niewolników zostaje przeniesiona w kontekst 
filozoficznej konwersacji” (duBois, 1991: 114), w trakcie której „filozoficzny oponent musi być tak jak niewolnik potraktowany z użyciem siły, bowiem prawda musi być od-kryta" (duBois, 1991: 126), wydobyta z ukrycia. Ujawnia się to $\mathrm{w}$ dialogu z sofistą, pod takim właśnie tytułem spisanym: „Podobnie bowiem jak niewolnik, tak Sofista ujawni prawdę jedynie w efekcie gwałtownego przesłuchania i nacisku" (Zybertowicz, 1995: 242). Czyli pod wpływem przemocy.

DuBois przekonuje, że utrwalony w zachodniej cywilizacji model poszukiwania prawdy oparty jest na metodach przemocowych. Zwłaszcza gdy co w tym kręgu rozpowszechnione - prawda pojmowana jest jako obecna w świecie, lecz ukryta i wymagająca odszukania. Docieranie do tak pojmowanej, ukrytej prawdy czy przedzieranie się ku niej konceptualizowane jest jako zmaganie czy wręcz walka („walka o prawdę” to popularna metaforyzacja), wymagająca użycia siły, a niekiedy wręcz przemocy dla usunięcia przeszkód stających lub wręcz intencjonalnie stawianych na drodze do prawdy. Platońska genealogia prawnej legitymizacji tortur jest explicite wyłożona przez Idelbara Avelara w eseju From Plato to Pinochet. Torture, confession, and the bistory of truth (Avelar, 2004).

Im tortury dotkliwsze, tym chętniej torturowani wyjawiają oczekiwane przez torturujących treści. Koncepcja przemocy jako metody dochodzenia do prawdy ma zatem charakter samopotwierdzający się, a więc jest w terminologii Poppera niefalsyfikowalna. Deklarowany przez torturowanych udział w spiskach czy zabronionych przez władzę (duchowną lub świecką) poczynaniach jest równie niefalsyfikowalny jak spółkowanie z diabłem, uczestnictwo w sabatach czarownic czy rzucanie uroku na sąsiadów albo bycie uprowadzonym i porzuconym przez kosmitów. Każdy tyran, despota czy dyktator stosuje przemoc jako narzędzie, którego stosowanie uzasadniane jest koniecznością dotarcia do prawdy lub - częściej — jej utrwalenia. Żaden nie używa siły w imię jakiejśs swojej, a więc subiektywnej racji, którą można byłoby przeciwstawić innej i poddać pod debatę czy agonistyczną rywalizację. Występuje w imię obiektywnych wartości, których prawda jest jednym z filarów, a debata nad nimi jest pozbawiona sensu. Walki w imię prawdy ze świadomie szerzonymi kłamstwami domagali się członkowie NSDAP w 23 punkcie deklaracji programowej z 1920 roku. Czołowe pismo propagandowe nazistów „Der Stürmer” nosiło podtytuł „Wochenblatt zum Kampfe um die Wahrheit” (Pismo tygodniowe w walce o prawdę). O „wewnętrznej prawdzie i wielkości narodowego socjalizmu” przekonywał Heidegger w pierwotnej wersji swojego Wprowadzenia do metafizyki, egzaltując się w dziennikach, że dzięki pojawieniu się führera „świat znowu zmierza ku prawdzie” (za: Kopacki, 2014: 154). „Prawda” to tytuł najważniejszego organu sowieckich komunistów. „Prawda was wyzwoli” to motto wyznawców jednej

${ }^{1}$ Cytaty z prac obcojęzycznych, jeżeli nie zaznaczono inaczej, w przekładzie autora. 
$\mathrm{z}$ religii, szerzonej pod jego auspicjami przemocą $\mathrm{w}$ wielu regionach świata w okresie jego starożytnych i nowożytnych dziejów. Pod szyldem veritatis splendor działa ekspozytura zajadłego fanatyzmu i fundamentalizmu.

Ale przemoc występuje też w imieniu dobra - kolejnego elementu z $\mathrm{Pla}-$ tońskiej triady fundamentalnych wartości. Tortury i śmierć zadawano ofiarom inkwizycji nie tylko dla dobra publicznego, ale także ich własnego. Wyznanie grzechów (prawdy o swojej grzeszności), uzyskiwane wyrafinowanymi metodami zadawania bólu i cierpienia (muzea tortur je dokumentują i eksponują), uwalniało duszę - w myśl doktryny — od ich ciężaru, oczyszczało ją z nich i otwierało jej drogę do zbawienia. Aby uniemożliwić ponowne zamknięcie lub zawrócenie duszy z właściwej ścieżki, grożące poprzez recydywę grzesznych słów, myśli i uczynków, najskuteczniejsze było definitywne pozbawienie możliwości ich popełniania, czyli życia; martwi nie grzeszą. Po wydobytym torturami przyznaniu się do grzechów pozbawiano więc oczyszczonego w ten sposób grzesznika życia doczesnego, aby umożliwić mu osiągnięcie tego wiecznego. Podejście takie ma niewątpliwy związek z Platońską koncepcją ciała jako więzienia duszy.

Biskup Grzegorz Ryś wskazuje przesłanki takiego rozumowania i postępowania w doktrynie Konstantyna Filozofa (jednego z Braci Sołuńskich, zwanych Apostołami Słowian, patrona uniwersytetu w Nitrze), który na zarzuty o stosowaniu przez chrześcijan przemocy, mimo jej ewangelicznego zakazu, miał według kroniki odpowiedzieć: „Dla bliźnich my to czynimy, ażeby przez cielesną niewolę także i dusza ich nie popadła w niewolę" (Ryś, 2016: 45). Biskup Ryś wyjaśnia dalej:

przekonanie, że dla dobra duszy bliźniego można zastosować przemoc wobec jego ciała, powracało w historii Kościoła wielokrotnie. Takie podejście rzymskiego prawa do pogaństwa i do herezji dramatycznie zaowocowało jednak w średniowieczu procedurami inkwizycyjnymi (Ryś, 2016: 45).

Ale stosowanie przemocy dla utrwalania wiary nie było jedynie koncepcją myślicieli religijnych. Niccolò Machiavelli z przekąsem zauważał, że

wszyscy uzbrojeni prorocy zwyciężają, a bezbronni padają, czego przyczyną [...] jest i to, że natura ludów jest zmienna, tatwo ich o czymś przekonać, lecz trudniej umocnić $\mathrm{w}$ tym przekonaniu. Trzeba więc urządzić się $\mathrm{w}$ ten sposób, aby gdy wierzyć przestaną, wlać im wiarę przemocą (Machiavelli, 1984: 51).

Fascynacja siłą i przemocą jako narzędziami ustanawiania prawdy i dobra ma swoich patronów zwłaszcza wśród filozofów oświeceniowych. Stefan Morawski wskazuje na epokę oświecenia jako przywracającą aktywistyczną tradycję platońską: 
Od czasów encyklopedystów, kiedy filozofia zaczęła być orientowana nie tylko teoretycznie, ale i praktycznie, odrestaurowana została tradycja platońska. Filozof miał nie tylko najmądrzej świat wyjaśniać i interpretować, ale także, i głównie, najlepiej go urządzać (Morawski, 1994: 70).

(Skądinąd postulowane czy nakazywane przez Platona opuszczenie jaskini i wyjście ku światłu określane bywa jako oświecenie, w języku angielskim enlightenment, tak samo jak nazwa epoki i filozoficznej doktryny). Jacob Talmon w swoich wnikliwych analizach procesów wyradzania się projektów demokracji w formy totalitarne, drobiazgowo wykazał potencjał przemocowy tkwiący w niektórych nurtach filozofii oświecenia. Część z nich pozwalała wręcz na sankcjonowanie siły i przemocy dla dokonywania przemian społecznych zgodnych z oświeceniowymi ideałami (Talmon, 2015: passim).

\section{W KRĘGU INSPIRACJI DARWINOWSKICH}

Zauważmy jednak, że najznaczniejszych wyrazicieli wspomniana wyżej fascynacja siłą i przemocą znalazła w darwinizmie i teoriach nim bezpośrednio inspirowanych ${ }^{2}$. Darwinowski obraz natury jako kształtowanej w toku i wyniku procesów selekcji naturalnej, a więc eliminacji osobników i gatunków gorzej przystosowanych, to wizja świata przepełnionego przemocą, gwałtem i śmiercią zadawaną słabszym przez silniejszych. To - ogólnie ujmując - triumf siły. „Znane są liczne przykłady takich działań, które sugerują, że przemoc jest charakterystyczna w ogóle dla świata zwierząt, jak zresztą wydaje się to wynikać z samej teorii ewolucji” (Lejman, 2004: 52). Albert Schweitzer, skądinąd upominający się o szacunek dla wszystkich form życia, ujął to znacznie bardziej dramatycznie:

przyroda jest piękna i wspaniała, gdy się jej przyglądać z wierzchu, ale wystarczy zagłębić się w jej mechanizm, aby człowieka ogarnęła zgroza. Jej okrucieństwo jest tak straszne! Najbardziej cenne życie pada ofiarą najsilniejszego. [...] Przyroda każe istotom żywym popełniać najpotworniejsze zbrodnie (za: Lazari-Pawłowska, 1992: 394).

Pomimo swej brutalności ewolucja wyłania bogactwo form i wielorakie piękno przyrody, tak ochoczo przez ludzi podziwiane. To stąd pozytywne waloryzacje i wielorakie inspiracje w kulturze postaciami drapieżników (orły, lwy, tygrysy, sokoły, wilki, skorpiony, pantery itd.), będących pod pewnymi względami ideałami wielu ludzi, co ma wielorakie odzwierciedlenie, począwszy od wierzeń totemicznych, na nazwach współczesnych drużyn sportowych

\footnotetext{
${ }^{2}$ Obszerny przegląd koncepcji uzasadniających dominację silnych osobników i grup w stosunkach społecznych oraz eliminację słabych zawiera praca Edwina Blacka (Black, 2004).
} 
kończąc. Piękno - trzecia w Platońskiej triadzie wartości idea fundamentalna - jest więc, przynajmniej w swej postaci naturalnej, wynikiem panowania siły i przemocy.

Dominuje jednak pogląd, że przyroda jest aksjologicznie neutralna. Ewolucja, w toku której się wyłania, nie jest ani dobra, ani zła. Nawet obraz przyrody przytoczony powyżej za Schweitzerem można zakwestionować poprzez zreinterpretowanie znaczenia pojęć. Na przykład przemoc czy agresję zdefiniować jako świadome działanie i wówczas uznać, że w świecie przyrody takie zjawiska nie występują (Lejman, 2004: 38n.). Wprawdzie etyk środowiskowy Holmes Rolston III podjął pewne usiłowania aksjologicznej interpretacji Darwinowskiego pojęcia lepiej przystosowanych, aby sugerować jakiś jego związek z pojęciem dobra (przystosowanie jest dobre, a więc ewolucja promująca lepiej przystosowanych jest dobra), ale porzucił ten trop, dostrzegając, że prowadzi w ślepy zaułek gloryfikacji naturalnej przemocy i siły (Rolston, 2012: 120-122). Lecz $\mathrm{w}$ etyce środowiskowej (ekoetyce) silny jest nurt afirmacji procesów selekcji naturalnej, postulujący powstrzymywanie się od nie tylko ingerencji w ich przebieg, lecz także ich oceniania. Ponieważ prymat i triumf silniejszych nad słabszymi to podstawowa jej reguła, zatem i tę należy przyjąć. Taki jest świat przyrody: ani dobry, ani zły.

Wspomniane manipulacje definicyjne mogą spowodować, że występowanie przemocy zostanie zanegowane nie tylko w przyrodzie, lecz także w świecie ludzkim. Taką właśnie definicyjną operację na pojęciu przemocy demaskuje A. Richard Konrad w polemice z Robertem Paulem Wolffem:

Otóż z pewnym zdumieniem odkrywamy, że w świetle wyjaśnienia przedstawionego przez Wolffa coś takiego jak przemoc w ogóle nie istnieje. „Problem przemocy”, który - jak się wydaje - budzi wielkie zainteresowanie i traktowany jest jako ważny, zostaje po prostu wyeliminowany na mocy definicyjnego dekretu. Niewątpliwie w taki właśnie sposób należy czytać Wolffa, jeśli poważnie przyjmujemy jego twierdzenie, że przemoc jest pojęciem, które ma sens jedynie w kategoriach politycznej prawomocności, a polityczna prawomocność jest mitem. Ergo (jak więc musimy wnioskować) przemoc jest mitem.

Niestety mimo sprawności, z którą Wolff tworzy definicje, zdarzenia takie, jak zabójstwa, zamachy bombowe, podpalenia czy inne czyny, które wielu ludzi uważa za akty przemocy, nie przestają mieć w sobie cechy zdecydowanej realności. Musimy zatem wyprowadzić konkluzję, że dokonana przez Wolffa analiza przemocy nie ma wartości dla zaniepokojonego tym problemem człowieka z ulicy; w istocie może się mu ona wydawać czystym nonsensem (Konrad, 2014: 234).

Próby rozwiązania problemu przemocy (na przykład domowej czy politycznej) poprzez definicyjne zredukowanie jej zakresu są powszechnie stosowane $\mathrm{w}$ politycznej propagandzie motywowanej ideologicznie. W ten równie przebiegły, co nieakceptowalny sposób „przemoc jako problem zostaje wyeliminowana 
na mocy definicyjnego dekretu, a więc nie wchodzi w zakres rozważań dotyczących tego, co należy czynić” (Konrad, 2014: 235).

W niektórych ujęciach jednak przemoc i agresja, występujące w świecie przyrody, waloryzowane są pozytywnie. Tak jest na przykład u Konrada Lorenza, według którego agresja służy optymalnemu rozmieszczeniu istot tego samego gatunku w dostępnej niszy ekologicznej, selekcji najlepiej przystosowanych oraz ochronie potomstwa (Lorenz, 1972: 79). „W tym znaczeniu przemoc, podobnie jak sama agresja, jest zjawiskiem pozytywnym” (Lejman, 2004: 40), co — jak stwierdza sam Lorenz — „działa dla dobra wielkiej sprawy życia” (Lorenz, 1972: 85). Skoro agresja i przemoc służą życiu (biologicznemu), to są usprawiedliwione.

Ale to nie oznacza, że należy akceptować takie reguły urzeczywistniania „wielkiej sprawy życia” także w przypadku gatunku bomo sapiens. Jeśli uznamy go za jeden tylko pośród innych, wówczas otwieramy drogę do afirmacji również $\mathrm{w}$ jego obrębie dominacji osobników silniejszych nad słabszymi, a więc triumfu siły w relacjach międzyludzkich.

Darwinizm społeczny ma tradycję równie długą jak teoria Darwina, a może i starszą. Prekursorem był Herbert Spencer. Skoro selekcja naturalna w biosferze prowadzi do ewolucyjnego postępu (w przystosowaniu do środowiska), mierzonego stopniem komplikacji i koordynacji funkcji życiowych organizmów, zatem jej przeniesienie na stosunki społeczne (międzyludzkie) też doprowadzi do (społecznego) postępu. Harmonijne piękno biosfery, wyłonione w toku ewolucji opartej na selekcji naturalnej, jest możliwe do osiągnięcia również w antroposferze, gdy ta zostanie znaturalizowana czy zrenaturalizowana. „W społecznej ewolucji ludzkości Spencer widział fragment większego procesu ewolucji biologicznej i uważat, że podlega ona prawom podobnym do zasady doboru naturalnego" (Fukuyama, 2017: 47). Postęp i doskonalenie ludzkości wymagają więc pozostawienia swobody mechanizmom eliminacji jednostek i grup nieprzystosowanych. „Cały wysiłek natury zmierza ku temu, by się ich pozbyć i zrobić miejsce dla lepszych. [...] Jeśli nie są dostatecznie przystosowani do życia, wymrą i tak będzie najlepiej” - przekonywał (za: Black, 2004: 47). A w innym miejscu dodawał: „aż dziwne, że wszyscy uznający słuszność teorii Darwina co do selekcji oraz walki o byt zarazem domagają się interwencji państwa, aby utrwalić byt osobników najmniej uzdolnionych” (za: Justyńska \& Justyński, 2013: 116-117).

Istota społecznego darwinizmu opiera się na kilku konstatacjach. Po pierwsze, istnieje analogia między organizmami biologicznymi a systemami społecznymi - podlegają one tym samym procesom walki o byt, opartym na wymogu przystosowania, przetrwania i reprodukcji. Po drugie, istnieją analogie między ewolucją organiczną a kulturową, wyrażające się w regule przetrwania najlepiej przystosowanych (w wypadku ewolucji kulturowej chodzi o instytucje, cywilizacje, państwa, społeczeństwa). Ostatecznie więc rozwój w ludzkiej historii dokonywany jest poprzez mechanizmy dziedziczenia, kulturowej 
reprodukcji (Hawkins, 1997: 99). Za Richardem Dawkinsem można to uznać za proces replikacji memów i przez analogię do „samolubnych genów” skonstatować paralelny prymat dominujących memów.

Kulminacją inspirowanej darwinizmem naturalizacji relacji międzyludzkich i stosunków społecznych jest nietzscheanizm. „Słabi i nieudani niech sczezną; pierwsza zasada naszej miłości dla ludzi. I pomóc należy im jeszcze do tego" (Nietzsche, 2003: 8). Jak to ujął jeden z pierwszych badaczy i krytyków koncepcji Nietzschego, dokonując jej streszczenia: „to, co silne, zwycięża i powinno zwyciężać, to, co słabe, upada i powinno upadać. «Śmierć słabemu» powiada [Nietzsche]. Jest to więc też wykroczeniem przeciw prawu natury, jeżeli ktoś wspiera i podtrzymuje to, co natura sama skazała na zagładę" (Vaihinger, 1904). Fascynacja nietzscheanizmem subtelnych intelektualistów wynika bodaj z tej samej tęsknoty do dominacji opartej na sile, której samym teoriom i ich autorom brakuje. Zresztą, podobnie jak Platon, Nietzsche formułuje skrajnie elitarystyczne ideały społeczne, co niektórym przedstawicielom tak czy inaczej rozumianych elit może się podobać.

Trzeba jednak koniecznie zaznaczyć, że fascynacja stosunkami panującymi w naturze i ekstrapolacja ich na relacje międzyludzkie oraz stosunki społeczne miała już w epoce darwinowskiej stanowczych oponentów. Bodaj najbardziej wpływowym był John Stuart Mill, który w opracowaniu $O$ naturze pisał:

albo prawdą jest, że powinniśmy zabijać, ponieważ Natura zabija, torturować, ponieważ Natura torturuje, rujnować i niszczyć, ponieważ Natura czyni podobnie, albo też w ogóle nie powinniśmy brać pod uwagę, co czyni Natura, a jedynie to, co jest dobre (Mill, 2008: 45).

Ale także bezpośredni uczeń i propagator koncepcji Darwina, zwany z powodu zajadłości, z jaką to czynił, „buldogiem Darwina”, Aldous Huxley stwierdzał:

powinniśmy zrozumieć raz na zawsze, że etyczny postęp społeczeństwa nie zależy od naśladowania kosmicznego procesu [ewolucji], a jeszcze mniej od ucieczki od niego, lecz od podjęcia walki z nim (za: Wright, 2004: 314).

Słowa autora odnoszą się szczególnie wyraźnie do tej cechy organizmów żywych, która ma najsilniejszy związek z ich zachowaniami agresywnymi i przemocowymi, mianowicie do terytorializmu (Lejman, 2004: 42-44). Wojny toczone $\mathrm{w}$ obronie własnego (uważanego za własne) terytorium byłyby zatem naśladownictwem przez człowieka innych istot, charakteryzujących się owym terytorialistycznym instynktem. Byłyby w tym sensie „naturalne”. Ale czy przez ów naturalizm usprawiedliwione? „Wojna jest powszechnym zjawiskiem w świecie zwierząt" (Lejman, 2004: 49), ale to nie znaczy, że jest tym samym usprawiedliwiona w świecie ludzi. 
Podobne wątpliwości rodzą się w przypadku drugiego z przemocogennych czynników naturalnych: zatłoczenia.

Badania prowadzone na zwierzętach w warunkach zatłoczenia wykazały, że rozrost zagęszczenia osiąga w pewnym momencie [wartość] krytyczną, po czym niszczy całą strukturę społeczną: zwierzęta chorują, zabijają potomstwo, walczą między sobą, aż do powrotu sytuacji wyjściowej (Lejman, 2004: 44).

Czy to sprawiedliwe akty agresji i przemocy w warunkach przeludnienia? Byłoby to równie absurdalne, jak usprawiedliwianie przemocy popełnianej przez mężczyzn przywołaniem prawidłowości, że samce wielu gatunków są agresywne i zaborcze.

Jakiekolwiek przykłady z natury (przyrody) mogą mieć sens eksplanacyjny, ale nie sankcjonujący w przypadku zachowań ludzkich. Zgodnie z zasadą $\mathrm{Hu}-$ me'a i regułą Moore'a żadne fakty nie uzasadniają powinności, deskrypcja nie prowadzi do preskrypcji. „Biologia nie usprawiedliwia” (Lejman, 2004: 46).

Wspomniane wcześniej jako charakterystyczne dla społecznego darwinizmu analogie antroposfery do biosfery, wyrażające się w organicystycznych koncepcjach społecznych, wywołują jeszcze inne kontrowersje. Ich elementem jest nie tylko funkcjonalne podporządkowanie poszczególnych części (komórek, tkanek, organów; jednostek, grup, wspólnot) organicznej całości, lecz także usytuowanie, a raczej zidentyfikowanie jej głowy (mózgu), centralnego ośrodka mającego koordynacyjną władzę nad tą całością. To dlatego koncepcje organicystyczne uważane są za niebezpieczne. Być może przesadne jest dostrzeganie bezpośrednich czy nawet pośrednich związków między tym aspektem darwinizmu a hitleryzmem, jak czyni to Richard Weikart (Weikart, 2006: passim). Faktem jest jednak obecność organicystycznej koncepcji społeczeństwa w deklaracji ideowej Obozu Narodowo-Radykalnego (pkt 5, https://www.onr.com.pl/deklaracja-ideowa/). Szczególnie niebezpieczne są metaforyzacje społeczeństwa jako „zdrowego” organizmu, z którego trzeba usunąć „chore” tkanki lub wyeliminować źródła „chorób”.

Porzucenie czy zakwestionowanie naturalizmu niekoniecznie prowadzi do porzucenia czy zakwestionowania eksplanacyjnej roli siły, przemocy i gwałtu w relacjach międzyludzkich i stosunkach społecznych. W dychotomicznej opozycji natura-kultura już dawno (co najmniej od czasów Jeana-Jacques'a Rousseau) to kultura została wskazana jako źródło przymusu i przemocy. Do rangi ujęcia dominującego podniósł te przekonania Sigmund Freud (niektórzy uznali, że historia nauk społecznych dzieli się na przedfreudowską i pofreudowską - tak znaczący miałby być przełom przez niego w tym obszarze dokonany). Freudowskie rozumienie kultury jako źródła i formy zinstytucjonalizowanej przemocy jest powszechnie znane, skonstatujmy tu jedynie, że „daje ono mocne podstawy do określenia go jako zwolennika tzw. koercyjnej teorii społecznej”, a „koercyjne teorie społeczeństwa utrzymują, iż spójność i porządek 
w społeczeństwie opiera się na sile i przymusie, na dominacji jednych i podległości innych" (Wróbel, 2004: 78, 79).

\section{FALSYFIKACJA JAKO SELEKCJA}

Darwinowskie zasady selekcji prowadzącej do wyłonienia najlepiej przystosowanych bywają ekstrapolowane na stosunki w świecie teorii naukowych i filozoficznych. Taki jest w istocie charakter Popperowskiego falsyfikacjonizmu, nakazującego eliminację hipotez słabiej dostosowanych do realnego świata (Świata 1 w ujęciu Poppera), aby wyłonić te lepiej dostosowane. „Krytyczny racjonalista K. Popper, twórca falsyfikacjonizmu, stosował metaforę nauki jako «zbrojnej walki o przeżycie najbardziej przystosowanej teorii». [...] Było to zapewne związane $\mathrm{z}$ inspiracjami ewolucjonizmem darwinowskim, gdzie selekcja naturalna (u Poppera była to selekcja polegająca na falsyfikacji) odgrywała decydującą rolę w rozwoju organizmów żywych" (Bieszczad, 2013: 147). Racjonalny krytycyzm - podstawa działalności badawczej w nauce i filozofii - ma służyć ostrej i bezwzględnej selekcji dokonywanej na drodze do wiedzy obiektywnej. Nauka i filozofia są więc obszarami ostrej rywalizacji (walki o byt, o przetrwanie) między konkurencyjnymi i zwalczającymi się hipotezami, z której zwycięsko - ale tylko tymczasowo, jak w świecie przyrody - wychodzi ta, której konkurentki do zdominowania wyznaczonego obszaru (w tym przypadku wiedzy) zostały wyeliminowane. Dokonuje się to poprzez „procesy selekcji, wyeliminowania słabszych rodzajów wiedzy” (Bińczyk, 1999: 71). Co więcej, „wiedzę naukową wyróżnia to, że walka o byt w jej ramach jest trudniejsza wskutek świadomej i systematycznej krytyki naszych teorii” (Chmielewski, 1995: 115).

Przemoc używana do eliminacji hipotez słabiej (eksplanacyjnie) dostosowanych nie ma, oczywiście, charakteru fizycznego, lecz symboliczny (Chmielewski, 1995: 115). Jest wyrazem dominacji pewnego, aktualnie obowiązującego paradygmatu. Ale definicja przemocy symbolicznej, podana przez inicjatora tego pojęcia Pierre'a Bourdieu, niemal pokrywa się z definicją paradygmatu.

Przemoc symboliczna stanowi przymus, realizowany tylko za pośrednictwem zgody, której zdominowany nie może nie udzielić dominującemu (a więc zgody na dominację), ponieważ aby nad tym się zastanawiać i zastanawiać się nad sobą, albo ściślej aby zastanawiać się nad swoją relacją z nim, może posługiwać się jedynie narzędziami poznawczymi, które posiada wspólnie z dominującym (Bourdieu, 2006: 242).

\section{A jak pisze Thomas Kuhn:}

Uczeni opierają się w swoich badaniach na modelach, które poznali w procesie kształcenia się, a następnie korzystania z literatury, nie zdając sobie często, a nawet nie 
musząc sobie zdawać sprawy z tego, jakim to cechom te modele zawdzięczają swój status wspólnotowych paradygmatów (Kuhn, 1968: 78).

Paul Feyerabend jest bardziej dosadny, bo wprost stwierdza, że „interesy, przymus, propaganda oraz techniki «prania mózgu» odgrywają znacznie większą rolę w rozwoju naszej wiedzy i w rozwoju nauki, niż to się powszechnie uważa” (Feyerabend, 1996: 25).

Oczywiście konstatacja ta nie jest przesłanką afirmacji, lecz negacji takich form i metod osiągania dominacji w nauce i systemie wiedzy.

Popperowski falsyfikacjonizm jako narzędzie selekcji hipotez proponuje odwołanie się do klasycznej definicji prawdy jako zgodności z faktami (to fakty mają siłę falsyfikacyjną i pełnią rolę selekcyjną). Lecz według wykładni dominującej we współczesnej filozofii nauki nie istnieją „,czyste”, „nagie” czy „gołe” fakty, bowiem każda obserwacja jest interpretacją (nie ma wiedzy niezinterpretowanej). A interpretacja jest dokonywana według dominującego modelu (paradygmatu) interpretacyjnego ${ }^{3}$. Rzekome czy deklaratywne dążenie do prawdy jest w istocie postugiwaniem się nią (a raczej jej pojęciem) do narzucania dominacji, czyli władzy. „System władza/wiedza (gdyż władzy nie można nigdy oddzielić od wiedzy) jest tym, co zarazem dominuje i dokonuje selekcji” (Wróbel, 2004: 83). Kartezjańska egalitaryzacja dostępu do wiedzy i prawdy (słynna teza o równych u wszystkich zasobach rozumu, otwierająca Rozprawe o metodzie) została zdekonstruowana przez postoświeceniową i postracjonalistyczną krytykę jako iluzja i mistyfikacja. Wiedza i prawda, jak przekonuje Michel Foucault, stają się narzędziami przemocy z każdą władzą związanej oraz w sprawowaniu władzy uprawnionej.

Podstawową funkcją dominującej wiedzy jest podtrzymywanie i narzucanie obowiązującej zbiorowej fikcji. [...] To, co rozpoznajemy jako rzeczywistość, jest fikcją, która uzyskała moc obowiązującą [...]. A panująca fikcja ustanawia nieodzowny dla zaistnienia sfery publicznej porządek dyskursu. Jeśli ktoś chce, by jego stowa były traktowane serio, musi ją uznawać. To w jej ramach możliwe jest ustalanie zdań prawdziwych i przeliczanie ich na inne zdania prawdziwe (Ostolski, 2003: 136, 165).

Prawda staje się narzędziem dominacji instytucjonalnie zalegitymizowanej fikcji ${ }^{4}$. „Prawda jest granica, wykwitem władzy. To walka o władzę wyznacza

${ }^{3}$ Nie jest to bynajmniej jakaś supozycja postmodernistyczna; już Bertrand Russell zauważył zgryźliwie: „wydaje się, że zwierzęta zachowują się w sposób wykazujący słuszność filozofii przyjętej przez obserwujących je ludzi [...]. Za panowania królowej Wiktorii wszystkie małpy żyły w cnotliwej monogamii, lecz w rozwiązłym wieku dwudziestym moralność ich fatalnie się obniżyła" (za: Lejman, 2004: 48). Tendencja taka występuje także obecnie: ekolodzy przedstawiają na ogół biosferę i ekosystemy jako harmonijną koegzystencję gatunków, natomiast etolodzy pokazują agresję, przemoc i dominację jako zjawiska w przyrodzie powszechne.

${ }^{4}$ Skądinąd Foucault inspirował się filozofią Nietzschego do tego stopnia, że w jednym z ostatnich wywiadów stwierdzit, iż „gdyby chciał być pretensjonalny, określitby siebie jako 
strukturę wiedzy, a ta z kolei współtworzy nasz świat” (Bińczyk, 1999: 68). Społeczne tworzenie rzeczywistości, zgodnie z formułą Bergera i Luckmanna, odbywa się w warunkach rywalizacji o władzę nad procesami owego tworzenia.

Charakterystyczne dla filozofii - a niektórzy twierdzą, że nawet konstytutywne dla niej - jest dążenie do uzyskania wiedzy pewnej (pewności epistemicznej, domknięcia poznawczego). Badaczki procesów i tendencji z tym dążeniem związanych stwierdzają, że korelują one z gotowością do afirmacji przemocy. Osoby o silnie odczuwanej potrzebie domknięcia poznawczego (silnej nietolerancji niepewności) są bardziej skłonne do akceptacji przemocowych metod jej zaspokajania (Kossowska, Szumowska, \& Szwed, 2018: 156-158).

Nieprzebierającą często w środkach walkę o eliminację i dominację teorii rzeczywistości zdezawuował Albert Camus w imię prymatu egzystencji ludzkiej. Pochwalit Galileusza za wyparcie się teorii heliocentrycznej w obliczu inkwizycyjnej groźby pozbawienia życia, zapewne poprzedzonego torturami.

Galileusz, który był w posiadaniu ważnej prawdy naukowej, zaparł się jej najłatwiej $\mathrm{w}$ świecie, ledwie zagroziła jego życiu. W pewnym sensie zrobił dobrze. Ta prawda nie była warta stosu. Jest rzeczą głęboko obojętną, czy ziemia kręci się wokół słońca, czy na odwrót. W gruncie rzeczy to kwestia błaha (Camus, 2004: 67).

Rywalizacja o władzę nad procesami tworzenia obrazu rzeczywistości poprzez narzucanie (także siłą i przemocą) dominującej narracji o świecie nie jest warta trofeum, które ma zdobyć, celu, jaki ma osiągnąć.

\section{SIŁA JAKO METODA UTRWALENIA DOMINUJĄCEJ NARRACJI}

Aby definitywnie skończyć z możliwą dominacją i wynikającą z niej przemocą symboliczną w naukowym dyskursie, postmodernizm proklamuje kres metanarracji, a więc nadrzędnej czy dominującej metody interpretacyjnej, oraz dekonstruuje prawdę jako jej legitymizację. Dla przeciwstawienia się nowoczesnej przemocy symbolicznej Gianni Vattimo proponuje „myślenie słabe”, wyrzekające się pragnienia dominacji (Vattimo, 2003).

Ideał równoprawności narracji jest jednak trudno spełnialny i psychologicznie niełatwy do utrzymania. W praktyce więc prawie każdy preferuje jakąś narrację, wybierając ją spośród innych według jakiegoś kryterium. Jeśli tym kryterium nie jest prawda, może stać się nim siła. W najlepszym przypadku siła oddziaływania, czyli samoistna atrakcyjność i powab (skądinąd naukowcy często przywołują piękno, harmonijną konstrukcję czy zgrabny kształt teorii jako argument na jej rzecz (Szynkiewicz, 2009: 42n.)). W gorszym — siła perswazji,

Nietzscheanistę”, a „oddziaływanie Nietzschego na teksty Foucaulta jest niemalże oczywiste” (za: Wróbel, 2004: 82). 
czyli technik erystycznych lub wprost manipulatorskich. W najgorszym — siła agresji, z jaką konkurencyjne interpretacje są zwalczane, a narzucane te preferowane. Internet, będący współczesnym odpowiednikiem agory, jest areną, na której dominują te ostatnie, najgorsze (jeśli nie liczyć fizycznych) formy agresji, siły i dominacji w zwalczaniu konkurencyjnych narracji. Fakty są selekcjonowane pod kątem zgodności z tą dominującą (w danej grupie, środowisku społecznym). (Dzieje się to wręcz automatycznie, poprzez cyfrowe algorytmy dobierające treści przekazu do wzorów narracyjnych preferowanych wcześniej przez użytkownika, często zresztą mu podsuwanych czy zgoła narzucanych). To nie fakty determinują wybór narracji, lecz dobierane są do dominującej narracji, aby tę dominację umocnić.

To smutna konstatacja, że w wyniku dekonstrukcji prawdy — postrzeganej przez postmodernistów jako narzędzie władzy i dominacji — oraz proklamacji przez nich równoprawności narracji wyłonił się prymat teorii i interpretacji najbardziej agresywnie, nachalnie i bezwzględnie proliferowanych. Dekonstrukcja i eliminacja prawdy jako narzędzia przemocy nie doprowadziły bynajmniej do wyeliminowania samej przemocy, lecz do umożliwienia ekspansji innych jej form, nieskrępowanych wymogiem prawdziwości. Skoro zakwestionowaniu uległy kryteria teoretyczne (a ściślej: metateoretyczne, jak prawda), to zastąpiły je pragmatyczne, a wśród nich legitymizowane poprzez siłę. Skoro pewna narracja przemogła inne i przedarła się zwycięsko przez ich gąszcz, budzi się pokusa przypisania jej jakichś walorów, dzięki którym zdołała to uczynić. Nie zawsze dostrzega się, że głównym albo wręcz jedynym jest siła pozostająca na usługach przemocy, nie tylko symbolicznej. Jak przestrzega Manuel Castells, władza (w sieci i poprzez sieć, „władza komunikacji” — jak brzmi tytuł jego dzieła) w ten sposób uzyskana jest niekontrolowalna ani przez państwo, ani przez społeczeństwo, ani przez kulturę (Castells, 2013). Jest więc szczególnie niebezpieczna. Na pocieszenie można jednak przytoczyć konstatację, że „w ludzkim zachowaniu czy myśleniu nie ma (o ile wiemy) nic nieuchronnego i dotyczy to również wszystkiego, co można by powiedzieć o przemocy" (Konrad, 2014: 241).

\section{BIBLIOGRAFIA}

Avelar, I. (2004). From Plato to Pinochet. Torture, confession, and the history of truth (s. 2549). W: I. Avelar. The letter of violence. Essays on narrative, etbics, and politics. New York: Palgrave McMillan.

Bartula, P. (2019). Dzieła zebrane. Kraków: Księgarnia Akademicka.

Bieszczad, B. (2013). Pedagogika i jezyk. Perspektywa ponowoczesna. Kraków: Wydawnictwo Uniwersytetu Jagiellońskiego.

Bińczyk, E. (1999). O czym szepcze władza (w ujęciu Michela Foucaulta). Przeglad Artystyczno-Literacki, 9, 67-74. 
Black, E. (2004). Wojna przeciw słabym. Eugenika i amerykańska kampania na rzecz stworzenia rasy panów. (Przeł. H. Jankowska). Warszawa: Muza.

Bourdieu, P. (2006). Medytacje pascaliańskie. (Przeł. K. Wakar). Warszawa: Oficyna Naukowa.

Castells, M. (2013). Władza komunikacji. (Przeł. J. Jedliński, P. Tomanek). Warszawa: Wydawnictwo Naukowe PWN.

Camus, A. (2004). Mit Syzyfa (s. 61-199). W: A. Camus. Mit Syzyfa i inne eseje. (Przeł. J. Guze). Warszawa: Muza.

Chmielewski, A. (1995). Filozofia Poppera. Analiza krytyczna. Wrocław: Wydawnictwo Uniwersytetu Wrocławskiego.

duBois, P. (1991). Torture and truth. New York-London: Routledge.

Feyerabend, P. (1996). Przeciw metodzie. (Przeł. S. Wiertlewski). Wrocław: Siedmioróg.

Fukuyama, F. (2017). Koniec bistorii i ostatni człowiek. (Przeł. T. Bieroń \& M. Wichrowski). Kraków: Znak.

Hawkins, M. (1997). Social darwinism in European and American thought 1860-1945. Nature as model and nature as threat. Cambridge: Cambridge University Press.

Justyńska, I. \& Justyński, J. (2013). Historia myśli socjologiczno-ekonomicznej. Warszawa: Lex.

Konrad, R.A. (2014). Filozof wobec przemocy. (Przet. D. Chabrajska). Ethos, 2(106), 231-242.

Kopacki, K. (2014). Gdy nie potrafimy zagrozić myśli, atakujemy jej autora. Przegląd Polityczny, 126.

Kossowska, M., Szumowska, E., \& Szwed, P. (2018). Tolerancja w czasach niepewności. Sopot: Smak słowa.

Kuhn, T. (1968). Struktura rewolucji naukowych. (Przeł. H. Ostromęcka). Warszawa: Państwowe Wydawnictwo Naukowe.

Lazari-Pawłowska, I. (1992). Etyka. Pisma wybrane. (Wybór, oprac. i red. P.J. Smoczyński). Wrocław: Ossolineum.

Lejman, J. (2004). Przemoc w świecie zwierząt. Wstęp do analizy ludzkiej agresywności (s. 3766). W: J. Mizińska \& M. Kociuba (Red.). Przemoc i filozofia. Lublin: Wydawnictwo Uniwersytetu Marii Curie-Skłodowskiej.

Lorenz, K. (1972). Tak zwane zło. (Przeł. A.M. Tauszyńska). Warszawa: Państwowy Instytut Wydawniczy.

Machiavelli, N. (1984). Książę (s. 33-116). (Przeł. Cz. Nanke). W: N. Machiavelli. Wybór pism. Warszawa: Państwowy Instytut Wydawniczy.

Mill, J.S. (2008). O naturze. (Przeł. M. Warchala). Warszawa: Fundacja Res Publica.

Morawski, S. (1994). Na tropach modernizmu jako formacji kulturowej. Teksty Drugie, 5/6, 62-78.

Nietzsche, F. (2003). Antychryst. (Przeł. L. Staff). Kraków: Zielona Sowa.

ONR - Nowa deklaracja ideowa, https://www.onr.com.pl/deklaracja-ideowa/

Ostolski, A. (2003). Dyskurs u władzy. Filozofia polityczna Michela Foucaulta. Etyka, 36, 159-172.

Rolston, H. III. (2012). A new environmental etbics. The next millennium for life on Earth. New York-London: Routledge.

Ryś, G. (2016). Jeden, święty, powszechny, apostolski. Spotkania z bistoria Kościoła. Kraków: Znak.

Szynkiewicz, M. (2009). Teorie ostateczne w naukach przyrodniczych. Poznań: Wydawnictwo Uniwersytetu im. Adama Mickiewicza.

Talmon, J. (2015). Źródła demokracji totalitarnej. (Przeł. A. Ehrlich). Kraków: Universitas.

Vaihinger, J. (1904). Filozofia Nietzschego. (Przeł. K. Twardowski). Online: https://wolnelektury.pl/katalog/lektura/filozofia-nietzschego.html\#m1423081636702-2403827548 (05.06.2020). 
Vattimo, G. (2003). Dialektyka, różnica, myśl słaba. (Przeł. M. Surma \& A. Zawadzki). Teksty Drugie, 5, 124-136.

Weikart, R. (2004). From Darwin to Hitler. Evolutionary ethics, eugenics, and racism in Germany. New York: Palgrave Macmillan.

Wright, R. (2004). Moralne zwierzę. Dlaczego jesteśmy tacy, a nie inni. Psychologia ewolucyjna a życie codzienne. (Przeł. H. Jankowska). Warszawa: Prószyński i s-ka.

Wróbel, Sz. (2004). Władza i autorytet. Przypadek Freuda i Foucaulta (s. 67-100). W: J. Mizińska \& M. Kociuba (Red.). Przemoc i filozofia. Lublin: Wydawnictwo Uniwersytetu Marii Curie-Skłodowskiej.

Zybertowicz, A. (1995). Przemoc i poznanie. Studium z nie-klasycznej socjologii wiedzy. Toruń: Wydawnictwo Uniwersytetu Mikołaja Kopernika. 
